\title{
How Cold Can You Go? Frost and Winter Protection for Grape
}

\author{
Joan R. Davenport, Markus Keller, and Lynn J. Mills \\ Crop and Soil Sciences, Irrigated Agriculture Research and Extension Center, \\ Washington State University, 24106 North Bunn Road, Prosser, WA 99350
}

Additional index words. Vitis vinifera, bud hardiness, pruning, grafting

\begin{abstract}
Although the inland Pacific Northwest has a warm climate during the growing season, grapes grown in this region may be exposed to colder than optimal temperatures at several times during the year. In addition to damage from spring and fall frosts, intermittent winters with little to no snow cover and subzero temperatures can cause vine dieback and death. Temperature patterns in the recent past indicate that both fall and midwinter are times when risk of bud damage from cold events is probable, making proper site selection and cultivar choice critical. Water is not used for frost protection in this climate, but wind machines have proven to be useful. In frost-prone sites, annual sucker growth with cane burying is practiced as an insurance strategy. Modifying pruning strategies has not been shown to be advantageous after fall cold events. If rootstocks are used, research has shown greater scion survival with higher graft positions.
\end{abstract}

Cold damage to grapes is a worldwide concern but is especially prominent in cool climates. A great deal of research has been conducted to document the types of injuries that can occur as a result of frost and freeze events (Fennell, 2004; Goffinet, 2001; Wample et al., 2001). Injury to the vine trunk also facilitates the systemic movement of Agrobacterium vitis and the formation of crown gall from endophytic infections with the bacterium (Burr and Otten, 1999). The climate of the inland Pacific Northwest is characterized by long, warm sunny days during the summer; large diurnal temperature fluctuations throughout spring, summer, and fall; and cold to freezing temperatures in the winter (http://weather.wsu.edu). Thus, there is potential for cold injury to grape from fall through the spring corresponding to the harvest, dormant, and early growth stages of the crop. The objective of this article is to provide an overview of the potential risks and possible protection methods for grapes in Washington state, where there are over 12,000 ha of wine and 10,000 ha of juice grapes in production (National Agricultural Statistics Service, 2007).

\section{TIMES OF RISK}

In central Washington, based on a 6-year average, daily mean and minimum temperatures from bud burst to harvest are above freezing, resulting in little risk for cold injury during June to September (Fig. 1). However, minimum temperatures for late season and postharvest dip precipitously low (less than $0{ }^{\circ} \mathrm{C}$ ), and mean and minimum dormant season temperatures are cold enough to present risk to grapes. Implicitly, multiyear average data obscure the specific temperatures of any given year, which suggests that the potential risk of cold injury is greater in some years than in others.

Historically, widespread cold temperature events that have the potential to damage grape

Received for publication 29 Oct. 2007. Accepted for publication 4 Dec. 2007. plants occur in Washington every 4 to 8 years (Wolfe, 2001). Site and variety play a role in the extent of the damage and are discussed in another section. The fine line between severe widespread damage and localized damage is well illustrated in Figure 2. During the 19951996 winter, temperatures in late January/ early February were cold enough (less than $-20{ }^{\circ} \mathrm{C}$ ) to result in severe bud damage in 'Cabernet Sauvignon', which was reflected in widespread damage throughout the growing region and a significantly reduced crop plus vine damage the next season (Wolfe, 2001). Although there also was a very cold period in early Jan. 2004, the minimum temperature was just above the level for bud damage to 'Cabernet Sauvignon' (Fig. 2), and overall crop and vine loss was much more localized (i.e., site-specific) than in 1996 (J. Watson, personal communication).

As Figure 1 shows, another period of potentially damaging cold temperatures is the postharvest period in late October/early November. Like with winter damage, the incidence of injury varies from year to year. Weather and bud cold-hardiness data from 2001 to 2004 illustrate this (Fig. 3). In 2001, daily minimum temperatures did not fall below the level of bud hardiness during the months of October or November (Fig. 3A). However, in the next 3 years, daily minimum temperatures fell below bud hardiness for some varieties at the very end of October (Fig. 3B-D). Some bud damage was indeed noted in these years (Keller and Mills, 2007). This suggests that the fall, in addition to midwinter, is a risky time for cold damage to grape vines in this growing region.

\section{SENSITIVITY OF DIFFERENT VARIETIES}

Cultivar differences in bud hardiness have been noted by other researchers (Fennell, 2004; Wolfe, 2001). For inland Washington, the majority of juice grapes produced is Concord grape (Vitis labruscana Bailey), whereas there are a number of different red and white wine grape (Vitis vinifera L.) varieties grown. Mills et al. (2006) evaluated dormant-season bud cold hardiness of a number of established and promising varieties. Of the well-established white varieties (Washington Wine Commission, 2007), 'Riesling' has bud hardiness to the lowest temperatures, whereas 'Gewürztraminer' has less hardy buds in the fall/early winter (October through mid-January, $\approx-13$ to $-20{ }^{\circ} \mathrm{C}$ ) and 'Chardonnay' has less hardy buds (near $-20^{\circ} \mathrm{C}$ ) between January and March (Fig. 4). Although the upcoming white variety 'Pinot Gris' shows bud hardiness that is intermediate between the well-established white wine varieties, 'Viognier' bud hardiness is low in the late October/early November $\left(-10\right.$ to $\left.-17^{\circ} \mathrm{C}\right)$ and December/January (near $-20{ }^{\circ} \mathrm{C}$ ) time periods that are associated with past damaging cold events (Fig. 4). The pattern of bud cold hardiness is a similar pattern as found in the well-established versus upcoming red wine varieties. 'Merlot', 'Cabernet Sauvignon', 'Cabernet Franc', and 'Syrah' have a fairly narrow range of bud hardiness temperatures (between -20 and $-23{ }^{\circ} \mathrm{C}$ December and January), and the upcoming variety, 'Malbec', if anything, shows bud hardiness to colder temperatures (Fig. 5). However, 'Mourvedre' and 'Sangiovese' buds are less hardy (between -18 and $-20{ }^{\circ} \mathrm{C}$ ) throughout the colder months of the year (Fig. 5B), suggesting that these varieties may be very site-limited in the region.

\section{MANAGEMENT TO MINIMIZE COLD DAMAGE}

To help grape producers assess the level of risk of cold injury to their plants, Washington State University monitors the cold hardiness of a range of $V$. vinifera and $V$. labruscana grape cultivars during the key months of the year using differential thermal analysis (Mills et al., 2006). Lethal temperatures for buds and cane xylem and phloem are posted online (http://winegra pes.wsu.edu/frigid.html) and updated weekly. Critical temperature adjustments need to be made for variation in site, because there are mesoclimatic differences between where cold-hardiness sample tissues are collected and each individual vineyard site. Because the temperature at which the bud and cane 


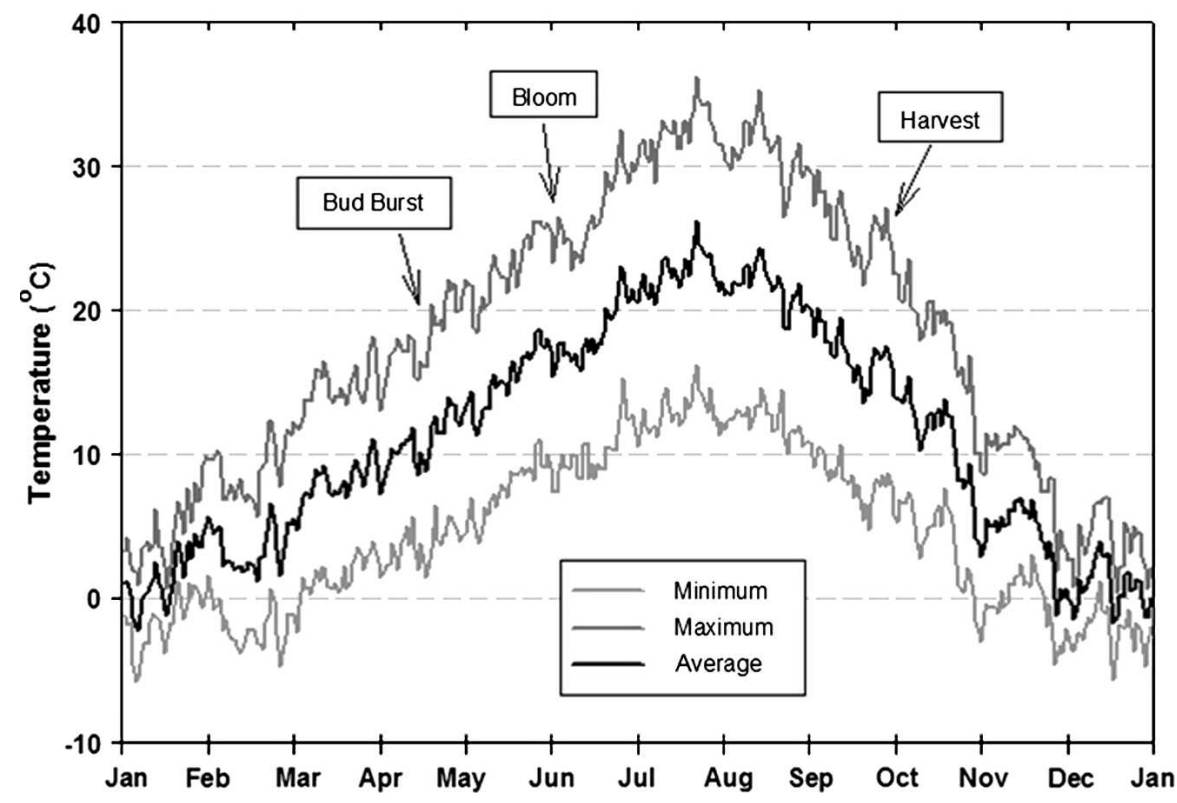

Fig. 1. Daily mean, maximum, and minimum temperature in central Washington calculated as an average of 6 years of temperature data from 2001-2006.
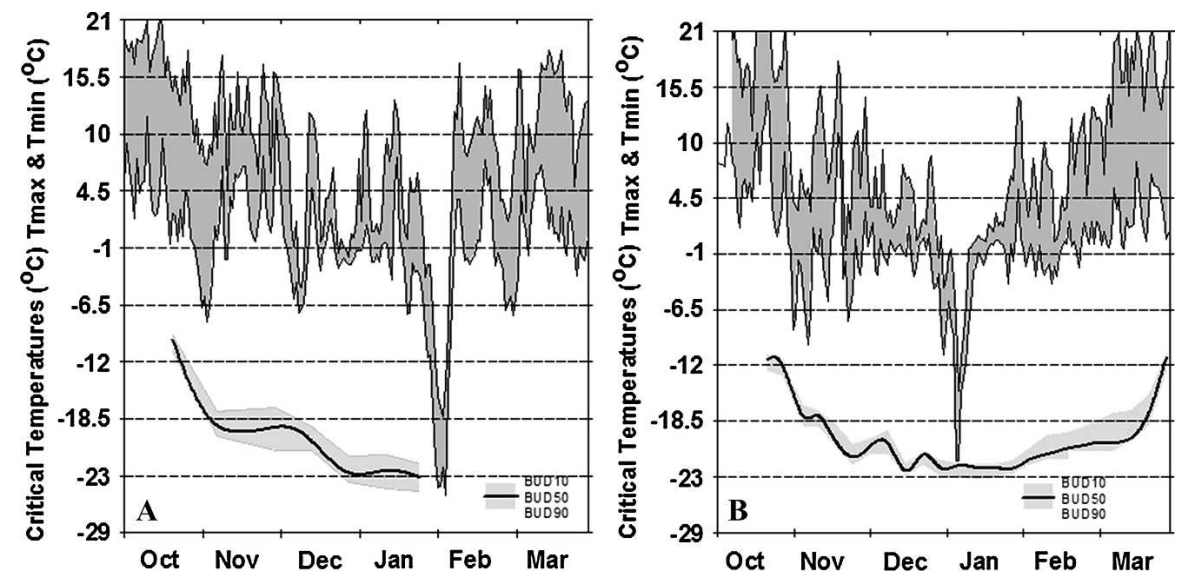

Fig. 2. Minimum to maximum temperature range in (A) 1995-1996 and (B) 2003-2003 from October through March and mean bud hardiness level (10\%, 50\%, and 90\% lethality) for 'Cabernet Sauvignon' in central Washington.

tissues of different varieties freeze continually changes throughout the winter, such information is critical for growers to make informed decisions concerning frost protection. Unlike with many other fruit crops, irrigation is not used for cold temperature protection for grapes in Washington for several reasons, most compelling of which is to keep water inputs to a minimum for product quality (Evans, 2001).

Spring and fall frost events are largely radiant with thermal inversions in this area (Evans, 2001); thus, site selection to avoid areas of cold air ponding is critical (Snyder and de Melo-Abreu, 2005; Wolf and Boyer, 2001). Therefore, the more cold-hardy juice grapes are generally grown at low elevation and in valley floors, whereas wine grapes are preferentially grown at higher elevation and on slopes with barrier-free cold air drainage. Nevertheless, there still can be a need to decrease cold damage risk in these sites. Although deacclimation. Moreover, cane hardiness was unaffected by crop load (Wolf, 2004). The same was true when 'Cabernet Sauvignon' grapes were harvested at different maturity levels or not harvested at all (Wample and Bary, 1992). Similarly, application of up to $224 \mathrm{~kg} \cdot \mathrm{ha}^{-1} \mathrm{~N}$ rarely decreased bud cold hardiness of 'Riesling' grapes in eastern Washington (Wample et al., 1993). These results suggest that, within commercially acceptable ranges and where vines can ripen their crop to maturity, neither crop load nor harvest date or vine nitrogen status should be expected to have detrimental effects on vine cold hardiness.

Deficit irrigation is widely used as a standard practice for high-quality wine grape production in the inland Northwest area. However, soil moisture is generally replenished after harvest to minimize root injury from winter freeze (Evans, 2001; Wample et al., 2001). Young vines, especially after their first season of growth, are sometimes buried using plows in the fall to prevent potentially lethal damage from unusually low temperatures. In addition, some growers, especially on valley floors, grow one or two suckers that are buried each fall and unburied in the spring to avoid cold injury. These buried canes serve as backup reserves in case a cold event kills the aboveground portion of the plant. Although costly, this practice is feasible in eastern Washington because, unlike in most of the rest of the world, grapes are generally grown on their own roots (i.e., not grafted to rootstocks).

The cold-hardier $V$. labruscana juice grapes are generally pruned soon after leaf fall; both manual and mechanical pruning are used for juice grapes (Keller et al., 2004). However, pruning of $V$. vinifera wine grapes, which are mostly cordon-trained and spurpruned in the inland Northwest, is usually delayed as long as possible to enable growers to compensate for bud damage suffered during the winter. Because hand pruning shortly before budbreak is not possible for many large vineyards as a result of labor shortage, growers often mechanically preprune their vines to relatively high bud numbers and then manually adjust final bud numbers later. In response to bud-damaging fall cold events, Keller and Mills (2007) compared pruning treatments to vary bud number and pruning time using standard spur pruning (prebudbreak, early March), late spur pruning (postbudbreak, middle of May), standard spur pruning with late repruning (double pruning, early March and middle of May), minimal pruning (no pruning except trimming of dead cane ends to facilitate bud counting), and minimal pruning with disbudding of all nodes (buds sliced off with a grafting knife). Overall, they found that late spur pruning had no advantage in cluster number or yield to standard spur pruning and that double pruning reduced bud number, cluster number, and yield. Additionally, their data showed that minimal pruning resulted in higher bud and cluster numbers, although this did not always translate into higher yields, 

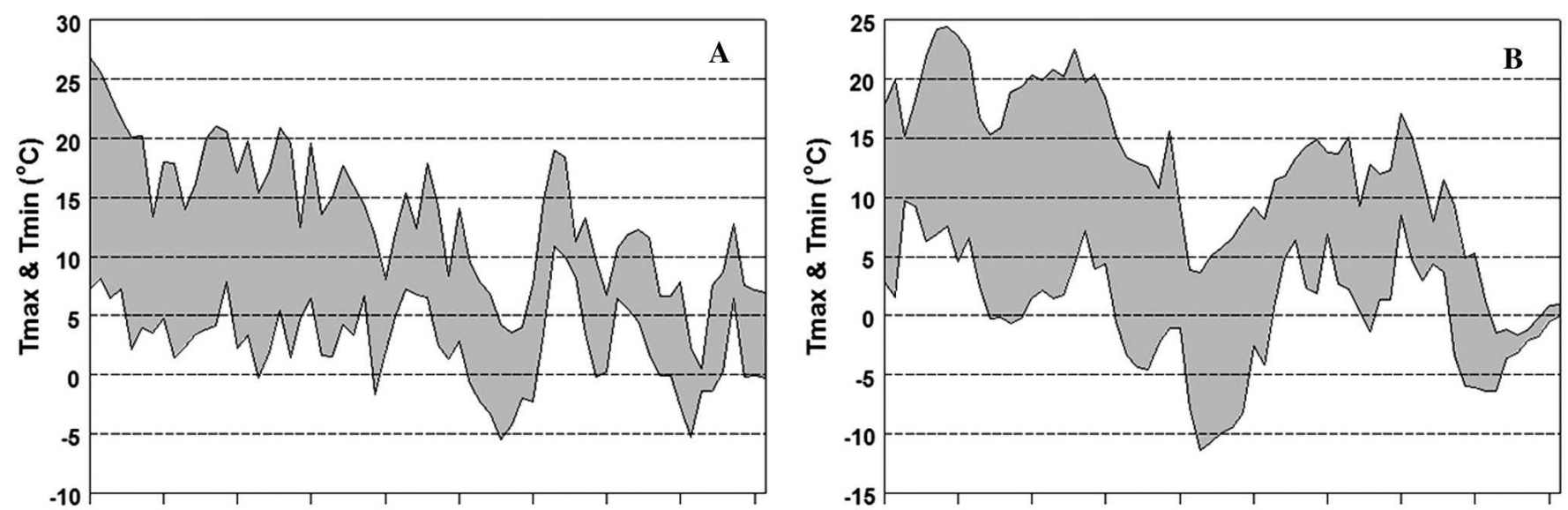

Oct 1 Oct 8 Oct 15 Oct 22 Oct 29 Nov 5 Nov 12 Nov 19 Nov 26 Dec 1 Oct 1 Oct 8 Oct 15 Oct 22 Oct 29 Nov 5 Nov 12 Nov 19 Nov 26 Dec 1
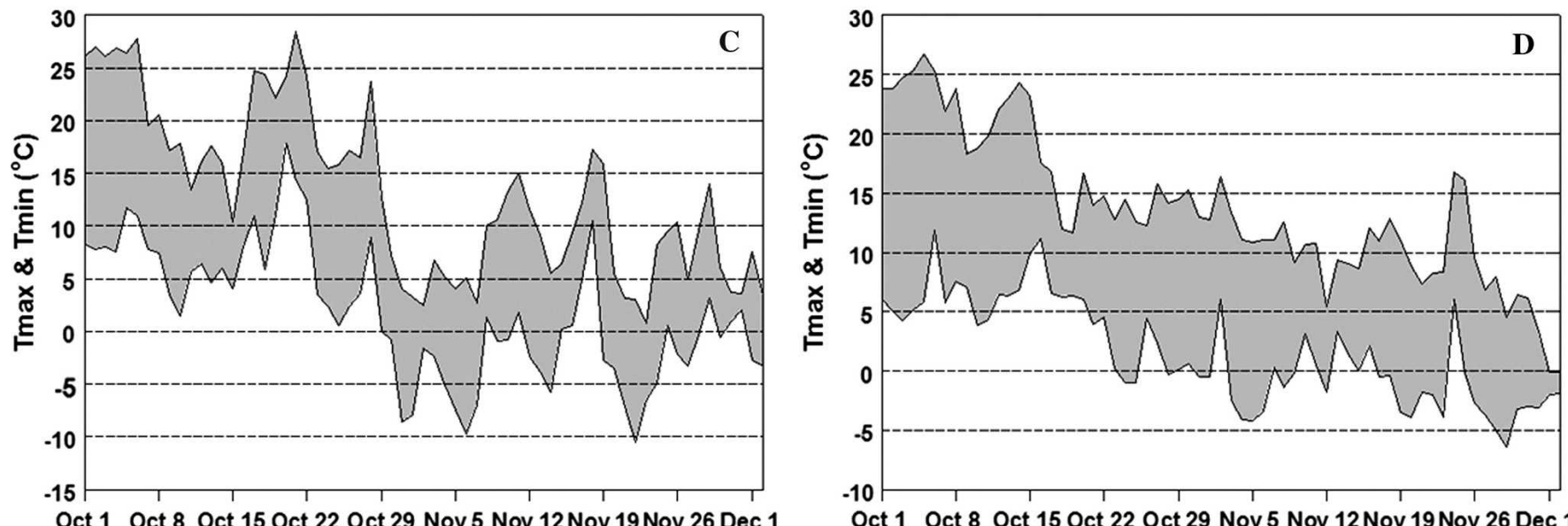

Oct 1 Oct 8 Oct 15 Oct 22 Oct 29 Nov 5 Nov 12 Nov 19 Nov 26 Dec 1

Fig. 3. Minimum to maximum autumn temperature ranges in (A) 2001, (B) 2002, (C) 2003, and (D) 2004 central Washington.

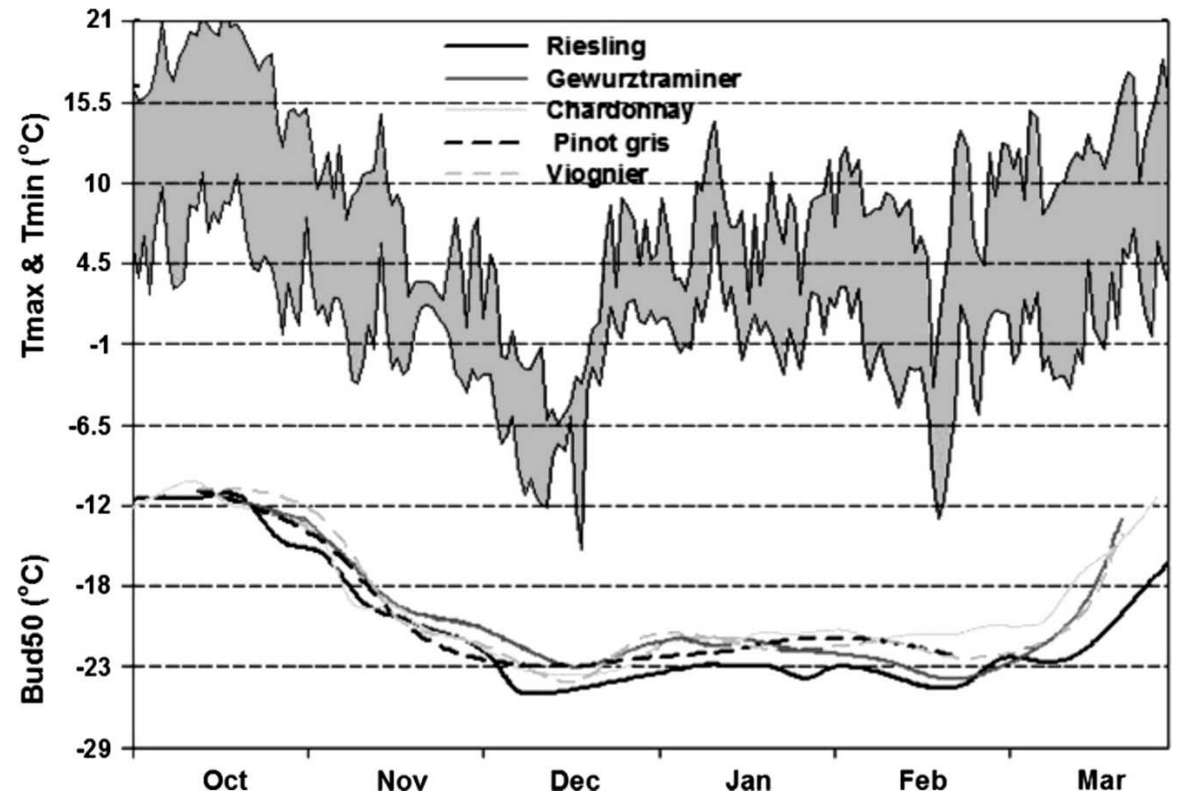

Fig. 4. Six-year (2001-2006) mean daily maximum and minimum temperature range and mean bud hardiness for six white wine grape varieties in central Washington.

largely as a result of reduced cluster size. Overall, this study suggests that minimal or light mechanical pruning may be a viable, inexpensive, and temporary strategy to achieve acceptable crop yields in seasons after relatively extensive bud damage and phloem injury as a result of very low fall or winter temperatures.

Although commercial grape production in eastern Washington predominantly relies on own-rooted plants, there is an interest in grafting to rootstocks. This is of economic concern, because grafted vines cannot simply be retrained from suckers after lethal cold injury to the trunk. Because the parents of most commercial rootstocks have evolved in North American regions that regularly experience cold winters (e.g., Galet, 1998; Pongrácz, 1983), they are likely to be coldhardier than their $V$. vinifera grafting partners. Therefore, one possible way of increasing winter survival could be to alter the height of grafting. To evaluate this, buds of 'Chardonnay', 'Merlot', and 'Syrah' were made low ( $27 \mathrm{~cm}$ aboveground surface) and for both 'Chardonnay' and 'Merlot', grafts also were made high $(69 \mathrm{~cm}$ aboveground surface) on the rootstock trunk on five different rootstocks. The data showed two- to threefold higher graft survival when grafts were made at the higher position than the lower position (Keller et al., 2007), suggesting that high grafts on a cold-tolerant rootstock has the potential to improve winter survival. Because many rootstocks are also more resistant to $A$. vitis than are $V$. vinifera cultivars, high grafting may also limit the incidence of crown gall after extreme cold events (Burr and Otten, 1999).

\section{CONCLUSIONS}

Overall, risk of grape vine injury from cold temperatures, in terms of both bud and phloem damage, in the inland Pacific Northwest is 

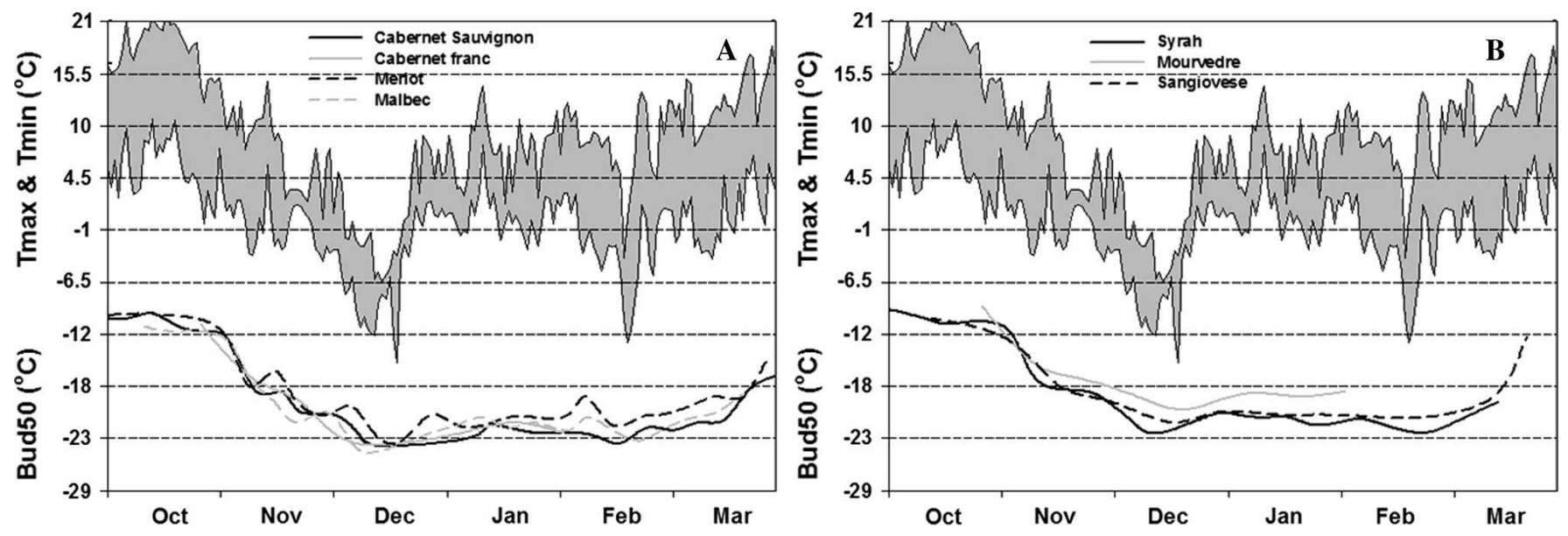

Fig. 5. Six-year (2001-2006) mean daily maximum and minimum temperature range and mean bud hardiness for seven red wine grape varieties in central Washington.

greatest in the fall with intermittent potential for localized damage during the winter. Because most of the spring and fall injuries are associated with radiant frost events, after site selection, use of wind machines to prevent cold air ponding has been shown to be the most effective management tool for cold injury in Washington. Attempts to modify pruning after cold damage have not resulted in improved crop yield or quality. Although the majority of the grapes in this area are ownrooted, research has shown that for grafting onto rootstocks, higher bud placement can improve bud survival and suggest that coldhardy rootstocks could be an option for winter cold-challenged sites.

\section{Literature Cited}

Burr, T.J. and L. Otten. 1999. Crown gall of grape: Biology and disease management. Annu. Rev. Phytopathol. 37:53-80.

Evans, R.G. 1999. Frost protection in orchards and vineyards. 8 Oct. 2007. <http://www.sidney.ars. usda.gov/Site_Publisher_Site/pdfs/personnel/ Frost $\% 20$ Protection\%20in\%20Orchards\%20and $\% 20$ Vineyards.pdf>.

Evans, R.G. 2001. The art of protecting grapevines from low temperature injury, p. 60-72. In: Rantz, J.M. (ed.). Proc. ASEV 50th Anniversary Annual Meeting, Amer. Soc. Enology Viticulture, Davis, CA.

Fennell, A. 2004. Freezing tolerance and injury in grapevines, p. 201-235. In: Arora, R. (ed.).
Adaptations and responses of woody plants to environmental stresses. The Haworth Press, Inc., Binghamton, NY.

Galet, P. 1998. Grape varieties and rootstock varieties. Translated from French by Smith, J. Oenoplurimédia, Chaintré, France.

Goffinet, M.C. 2001. The anatomy of low-temperature injury of grapevines, p. 94-100. In: Rantz, J.M. (ed.). Proc. ASEV 50th Anniversary Annual Meeting, Amer. Soc. Enology Viticulture, Davis, CA.

Keller, M. and L.J. Mills. 2007. Effect of pruning on recovery and productivity of cold-injured Merlot grapevines. Amer. J. Enol. Vitic. 58: 351-357.

Keller, M., L.J. Mills, and D.S. Hackett. 2007. Field grafting and cold injury: Grafting height but not rootstock affects scion survival. Proc. XV International Symposium Groupe d'Etude des Systèmes de Conduite de la Vigne, Poreč, Croatia. p. 294-300.

Keller, M., L.J. Mills, R.L. Wample, and S.E. Spayd. 2004. Crop load management in Concord grapes using different pruning techniques. Amer. J. Enol. Vitic. 55:35-50.

Mills, L.J., J.C. Ferguson, and M. Keller. 2006. Cold-hardiness evaluation of grapevine buds and cane tissues. Amer. J. Enol. Vitic. 57:194200.

National Agricultural Statistics Service. 2007. Grape release. 20 Sept. 2007. <http://www.nass.usda. gov/Statistics_by_State/Washington/Publications/ Fruit/grape07.pdf $>$.

Pongrácz, D.P. 1983. Rootstocks for grape-vines. David Philip Publisher, Cape Town, South Africa.
Synder, R.L. and J.P. de Melo-Abreu. 2005. Frost protection: Fundamentals, practices, and economics. Vol. 1. FAO Environ. Nat. Res. Series 10. FAO, Rome, Italy.

Wample, R.L. and A. Bary. 1992. Harvest date as a factor in carbohydrate storage and cold hardiness of Cabernet Sauvignon grapevines. J. Amer. Soc. Hort. Sci. 117:32-36.

Wample, R.L., S. Hartley, and L. Mills. 2001 Dynamics of grapevine cold hardiness, p. 8193. In: Rantz, J.M. (ed.). Proc. ASEV 50th Anniversary Annual Meeting, Amer. Soc. Enology Viticulture, Davis, CA.

Wample, R.L., S.E. Spayd, R.G. Evans, and R.G. Stevens. 1993. Nitrogen fertilization of White Riesling grapes in Washington: Nitrogen seasonal effects on bud cold hardiness and carbohydrate reserves. Amer. J. Enol. Vitic. 44:159-167.

Washington Wine Commission. 2007. Varieties. 8 Oct. 2007. <http://www.washingtonwine.org/ washington-wine/varieties>.

Wolf, T.K. 2004. Crop yield effects on cold hardiness of 'Cabernet Sauvignon' dormant buds. Acta Hort. 640:177-187.

Wolf, T.K. and J.D. Boyer. 2001. Site selection and other vine management principles and practices to minimize the threat of cold injury, p. 4959. In: Rantz, J.M. (ed.). Proc. ASEV 50th Anniversary Annual Meeting, Amer. Soc. Enology Viticulture, Davis, CA.

Wolfe, W. 2001. Vine and vineyard management following low temperature injury, p. 101-110. In: Rantz, J.M. (ed.). Proc. ASEV 50th Anniversary Annual Meeting, Amer. Soc. Enology Viticulture, Davis, CA. 